\begin{tabular}{|l|l|l||}
\hline \multicolumn{2}{|c|}{ PublisherInfo } \\
\hline \hline PublisherName & $:$ & BioMed Central \\
\hline \hline PublisherLocation & $:$ & London \\
\hline \hline PublisherImprintName & $:$ & BioMed Central \\
\hline \hline
\end{tabular}

\title{
Breast cancer linked to chromatin remodeling
}

\begin{tabular}{||l|l|l||}
\hline \multicolumn{2}{|c|}{ ArticleInfo } \\
\hline \hline ArticleID & $:$ & l733 \\
\hline \hline ArticleDOI & $:$ & $10.1186 /$ gb-spotlight-20000731-01 \\
\hline \hline ArticleCitationID & $:$ & spotlight-20000731-01 \\
\hline \hline ArticleSequenceNumber & $:$ & 170 \\
\hline \hline ArticleCategory & $:$ & Research news \\
\hline ArticleFirstPage & $:$ & 1 \\
\hline \hline ArticleLastPage & $:$ & 2 \\
\hline \hline & $:$ & RegistrationDate : 2000-07-31 \\
ArticleHistory & $:$ & OnlineDate \\
\hline \hline ArticleCopyright & $:$ & BioMed Central Ltd2000-07-31 \\
\hline \hline ArticleGrants & $:$ & \\
\hline \hline ArticleContext & $:$ & 130591111 \\
\hline \hline
\end{tabular}




\section{William Wells}

Email: wells@biotext.com

BRCA1 is a tumor-suppressor gene linked to familial breast and ovarian cancers. In the July 21 Cell, Bochar et al. find that the predominant BRCA1-containing complex in human cells is the SWI/SNFrelated chromatin remodeling complex (Cell 2000, 102:257-265). This may explain the multitude of properties that have been ascribed to BRCA1, including effects on transcription, DNA repair, and cellcycle checkpoints. Mutations in SNF5, another subunit of the SWI/SNF complex, have been shown to result in aggressive pediatric cancer, and a close inspection of other SWI/SNF proteins and genes may turn up other cancer culprits.

\section{References}

1. A strong candidate for the breast and ovarian cancer susceptibility gene BRCA1.

2. Cell, [http://www.cell.com/]

3. Truncating mutations of hSNF5/INI1 in aggressive paediatric cancer. 